\title{
Palaeontological Virtual Congress: A new way to make science
}

\section{Vicente D. Crespo and Esther Manzanares}

Vicente D. Crespo. Consejo Nacional de Investigaciones Científicas y Técnicas, División de Paleontología de Vertebrados, Museo de La Plata (UNLP), Paseo del Bosque s/n, B1900FWA La Plata, Argentina. vidacres@gmail.com Museo Paleontológico de Alpuente, Av. San Blas 17, Alpuente, 46178 Valencia, Spain Museu Valencia d'Història Natural, L'Hort de Feliu, P.O. Box 8460, Alginet, 46018 Valencia, Spain. Corresponding author Esther Manzanares. Departament de Botànica i Geologia, Universitat de València, Dr. Moliner 50, 46100, Burjassot, Valencia, Spain. Esther.Manzanares@uv.es Institut Cavanilles de Biodiversitat i Biologia Evolutiva, Catedrático José Beltrán Martínez 2, 46980 Paterna, Valencia, Spain

Keywords: Palaeontological Virtual Congress; palaeontology; internet; meeting; scientist

Submission: 8 October 2019. Acceptance: 24 October 2019.

\section{A NEW FORM OF SCIENTIFIC CONGRESS}

On the first month of 2018, one of the authors (VDC) of this preface had an interesting idea: to hold a virtual congress. At first, he did not know of the existence of this kind of congress, but a quick internet search showed him that there were some examples in the fields of medicine and veterinary medicine; however, it had never been done in palaeontology. For that reason, with the help of other co-workers from the Universitat de València, Museo Paleontológico de Alpuente and Museu Valencià d'Historia Natural, we decided to undertake this adventure.

The $1^{\text {st }}$ Palaeontological Virtual Congress (1st PVC; Figure 1) was born as the natural consequence of the evolution of our surrounding world and the emergence of new technologies that allow for a wide range of communication possibilities.
Within this context, the 1 st PVC represented the first attempt in palaeontology to take advantage of this new situation, being the first international palaeontological congress developed in an exclusively virtual environment. One of our main goals for this project was to give an international platform to the palaeontological research carried out by groups with limited economic resources. This new format combines the benefits of traditional meetings (i.e., providing a forum for discussion, merchandising, guest lectures, "field trips", an abstract book, etc.) with the advantages and simplicity of online platforms. It has reached a high number of palaeontologists around the world. We know the difficulties that researchers from developing countries, independent researchers, or researchers without grants have to travel to different congresses. So, thanks to the volunteer work of the

Crespo, Vicente D. and Manzanares, Esther. 2019. Palaeontological Virtual Congress: A new way to make science. Palaeontologia Electronica 22.3.pvc-preface 1-4. https://doi.org/10.26879/1037

palaeo-electronica.org/content/pvc-4

Copyright: October 2019 Paleontological Society.

This is an open access article distributed under the terms of Attribution-NonCommercial-ShareAlike 4.0 International (CC BY-NC-SA 4.0), which permits users to copy and redistribute the material in any medium or format, provided it is not used for commercial purposes and the original author and source are credited, with indications if any changes are made.

creativecommons.org/licenses/by-nc-sa/4.0/ 


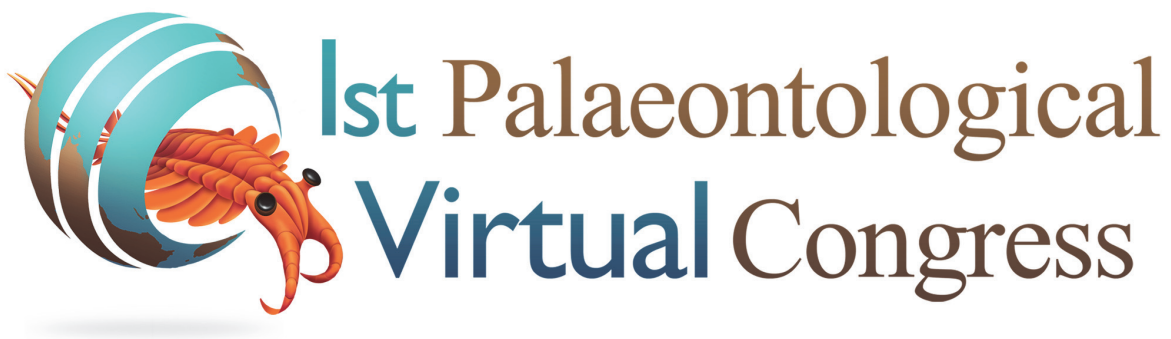

FIGURE 1. Logo of the 1st Palaeontological Virtual Congress, designed by Hugo Salais (source: author).

organising committee we could provide a low registration fee, which would allow for the high number of participants in the congress.

Additionally, in a world progressively more concerned about carbon emissions, these types of congresses are an excellent idea to share our work without the contamination associated with traditional meetings (including traveling by plane, car, or train).

\section{RESULTS}

\section{Participation}

Despite the novelty of this project and the reservations of some palaeontologists, the 1 st PVC exceeded our expectations: 376 palaeontologists and palaeontology enthusiasts from 41 different nations and five continents were part of this initiative. It is important to highlight that there were numerous contributions from South America, Africa, the Middle East and Eastern Europe, realizing our main goal of a palaeontological congress without barriers. Around 150 specialists peerreviewed the quality of the 154 contributions reported in this edition.

\section{Congress Format}

The congress was organized as in any traditional congress: keynotes carried by recognized specialists, general sessions and workshops and "field trips". In charge of the keynotes were Dr. Alexander M. Dunhill, Dr. Emilia Jarochowska with one of her students, Niklas Hohman, and last, but not least, Dr. Lars W. van den Hoek Ostende.

The participants had three forms in which to present their work: a video presentation, where the speaker presented in voice for 15 minutes along with presentation slides; presentation slides, without speaking, but with more text on each slide; or a traditional poster.
As in any meeting, all the contributions have been published in the abstract book "1st Palaeontological Virtual Congress. Book of abstracts. Palaeontology in the virtual era' (Crespo et al., 2018), that can be downloaded for free on our website.

\section{Workshops}

Palaeontology is a diverse discipline, which encompasses a variety of topics. The organising committee wanted to take advantage of this variety by allowing any palaeontologist to create their own workshop on their field of expertise. This idea had a very warm welcome, and 14 specific workshops and four general workshops were held on our virtual platform. These specific workshops were titled:

- Advances on conodont biostratigraphy, moderated by Pilar Navas-Parejo and R. Aaron Lara Peña from Estación Regional del Noroeste, Instituto de Geología, Universidad Nacional Autónoma de México (Mexico).

- $\quad$ Big equipment, small structures: modernised, new, and innovative techniques in fossil microanalysis, moderated by Bryan Shirley from Friedrich-Alexander-Universität Erlangen-Nürnberg (Germany) and Carlos Martínez-Pérez from Universitat de València (Spain) and University of Bristol (United Kingdom).

- $\quad$ Fossil insect-names, publications, databases, moderated by Jacek Szwedo and Dany Azar from Uniwersytet Gdański (Poland).

- Foundations of biological systematics, moderated by Rafael G. Souza from Departamento de Geologia e Paleontologia, Museu Nacional/Universidade Federal do Rio de Janeiro (Brazil).

- Inside the fossils: a palaeohistological point of view, moderated by Francesc Gascó from Grupo de Biología Evolutiva, UNED (Spain), Koen Stein from Vrije Universiteit Brussel (Belgium) and Maite Suñer from Museo Paleontológico de Alpuente (Spain).

- New insight about ambers: Mesozoic resin producers and productions, moderated by Eduardo Barrón 
and Enrique Peñalver from Museo Geominero, Instituto Geológico y Minero de España (Spain).

- Paleoart: reconstructing extinct life, moderated by Hugo Salais-López Universitat Jaume I, Castellón de la Plana (Spain) and Francesc Gascó from Grupo de Biología Evolutiva, UNED (Spain).

- Paleobiology and evolution of dinosaurs, moderated by Penélope Cruzado-Caballero and Ariel Hernán Méndez from Instituto de Investigaciones en Paleontología y Geología, Consejo Nacional de Investigaciones Científicas y Técnicas-UNRN (Argentina), Leonardo S. Filippi from Museo Municipal Argentino Urquiza, Rincón de los Sauces, Neuquén (Argentina) and Cristina Jiménez-Gomis from Universidad de La Laguna (Spain).

- Paleobotany: biostratigraphy, paleogeography, paleoenvironmental reconstructions and climatic change, moderated by Uxue Villanueva Amador and Alba Vicente Rodríguez from Estación Regional del Noroeste, Instituto de Geología, Universidad Nacional Autónoma de México (Mexico).

- $\quad$ Pterosaur paleobiology and evolution, moderated by Borja Holgado and Rodrigo V. Pêgas from Departamento de Geologia e Paleontologia, Museu Nacional/Universidade Federal do Rio de Janeiro (Brazil).

- $\quad$ Stratigraphic Palaeobiology: developing a toolbox for palaeobiologists, moderated by Emilia Jarochowska from GeoZentrum Nordbayern, FriedrichAlexander-Universität Erlangen-Nürnberg (Germany) and Christopher Dean from Imperial College London (United Kingdom).

- Taphonomy, moderated by María Dolores MarinMonfort and Sara García-Morato from Museo Nacional de Ciencias Naturales-CSIC, Madrid (Spain).

- The small mammals of the Neogene from Europe, moderated by Sílvia Jovells-Vaquè from Institut Català de Paleontologia Miquel Crusafont and Universitat Autònoma de Barcelona, Cerdanyola del Vallès (Spain) and Vicente D. Crespo from Museo Paleontológico de Alpuente, Alpuente (Spain), Museu Valencià D'Història Natural, Alginet (Spain) and Departament de Botánica i Geologia, Universitat de València, Burjassot (Spain).

- Vertebrate ichnofossils, moderated by Vanda Faria dos Santos from Departamento de Geologia, Faculdade de Ciências da Universidade de Lisboa (Portugal), Carlos de Santisteban from Departament de Botánica i Geologia, Universitat de València, Burjassot (Spain) and Maite Suñer from Museo Paleontológico de Alpuente, Alpuente (Spain).

The variety of workshops held during the congress provided all the participants a forum for the exchange of ideas and the opportunity to discuss the topic with specialists in that particular field.

\section{Virtual Field Trips}

The experimental nature of this congress allowed us to explore new forms of applying the benefits of the traditional meetings to a virtual world. For the 1 st PVC we realized two virtual "field trips", one in the natural history museum of the University of Valencia (Museu d'Història Natural de la Universitat de València) and the other in Mesozoic field localities and museum collections with dinosaurs and marine faunas from Alpuente (Valencia, Spain). These virtual field trips were 20-minute documentary films where an off-camera voice explained what the audience was viewing much like a guide in a classic field trip.

\section{Special Issue}

The other result of this congress was this special issue in Palaeontologia Electronica. When we planned the congress, we thought that this journal shared the same spirit. For this reason, we decided to make a special issue with the expanded abstracts that were presented in the congress. The works comprising this volume include a new skull of a giraffid from a classical site of Batallones (Spain) (Ríos and Morales, 2019), a taphonomic study of abrasion by water on the bones of rodents (García-Morato et al., 2019), and the study of a bipedal track using geometric morphometrics (Costa-Pérez et al., 2019).

\section{The Charitable Aims of the 1st PVC}

As we stated before, one of our principal achievements was to provide the possibility of global participation in an international scientific congress. Thanks to the simplicity of this new format, we could do it. The other new idea was the inexpensive registration. Usually this type of meeting in other fields has a registration fee of approximately 100 euros or more. However, thanks to the volunteer work of the organising committee we could charge a low registration fee (although we had some costs that prevented the lowest registration fee). In addition, at the end of the congress the proceeds from the sale of PVC merchandise were donated to Doctors Without Borders (Médecins Sans Frontières).

\section{The Future}

This was the first edition of the Palaeontological Virtual Congress, but this will not the last. After the meeting, we wanted to know the impression the 
congress had within the participants, so we made a survey to understand the experience of the congress participants. We asked them which aspects of the meeting they think will need to be improved in future editions. So, with their comments in mind, we are preparing new surprises and new forums in which participants can interact in the next congress that we are going to celebrate in May of 2020. We look forward to seeing you in the $2^{\text {nd }} \mathrm{PVC}$ !

\section{ACKNOWLEDGEMENTS}

Finally, we would like to thank all of the other members of the organising committee (C. Martínez-Pérez, R. Marquina-Blasco, M. Suñer, J.L. Herráiz, A. Gamonal, F.A.M. Arnal, H.G. Ferrón and $F$. Gascó), our colleagues for organizing and coordinating the different workshops, all of the authors for submitting their contributions and to the numerous reviewers that have made this volume and congress possible. We would like also to give special thanks to Palaeontologia Electronica, The Palaeontological Association, Museu d'Història Natural de la Universitat de València, Sociedad Geológica de España, Sociedad Española de Paleontología, Museo Geológico del Seminario de Barcelona, Associazione Italiana per lo Studio del Quaternario, Societa Paleontologica Italiana, Asociación Latinoamericana de Paleobotánica y Palinología, Paläontologische Gesellschaft, European Association of Vertebrate Palaeontologist, Geoscience Society of New Zealand, Paleowire, Transmitting Science, eLife, The Geological Society of America, Pander Society, Sociedad Mexicana de Paleontología and Paleontological Society that have supported this initiative, specially to the University of Valencia (the Department of Botany and Geology) for hosting the space to develop this project. Thanks are also due to the helpful comments on the original manuscript provided by D. Hembree.

\section{REFERENCES}

Costa-Pérez, M., Moratalla, J.J., and Marugán-Lobón, J. 2019. Studying bipedal dinosaur trackways using geometric morphometrics. Palaeontologia Electronica 22.3.pvc-3: 1-13. https://doi.org/10.26879/980 palaeo-electronica.org/content/pvc-3

Crespo, V.D., Manzanares, E., Marquina-Blasco, R., Suñer, M., Herráiz, J.L., Gamonal, A., Arnal, F. A.M., Ferrón, H.G., Gascó, F., and Martínez-Pérez, C. 2018. 1st Palaeontological Virtual Congress. Book of Abstracts. Palaeontology in the Virtual Era. Universitat de València, Museo de Alpuente and Museu Valencià d'Historia Natural, Valencia

García-Morato, S., Marin-Monfort, M.D., and Fernández-Jalvo, Y. 2019. Rolling bones: A preliminary study of micromammal abrasion on different initial taphonomic stages. Palaeontologia Electronica 22.2.pvc-2: 1-16. https://doi.org/10.26879/974 palaeo-electronica.org/content/pvc-2

Ríos, M. and Morales, J. 2019. A new skull of Decennatherium rex Ríos, Sánchez and Morales, 2017 from Batallones-4 (upper Vallesian, MN10, Madrid, Spain). Palaeontologia Electronica 22.2.pvc-1: 1-16. https://doi.org/10.26879/965 palaeo-electronica.org/content/pvc-1 